\title{
Can Fund Managers Select Outperforming REITs? Examining Fund Holdings and Trades
}

\author{
Gjergji Cici,* Jack Corgel** and Scott Gibson***
}

Despite at least six empirical studies published since 2000 designed to assess fund managers' Real Estate Investment Trust (REIT)-selection ability, their skill remains in question. Unlike previous studies, we examine fund holdings and trades of REITs to answer this question. This approach allows us to explicitly account for portfolio rebalancing that alters REIT-characteristic weights of fund portfolios. Results show that fund managers, after controlling for property type, size and momentum, generated significant positive alpha with their securitiesselection ability. To understand the sources of such ability, we examine whether fund managers who followed certain trading strategies outperformed relative to other managers. The potential trading strategies are based on public information related to geographic concentration, net-asset-value-to-price ratios, income and appreciation styles and leverage of the underlying REITs. Comparative and regression analyses show that none of the strategies fully explains why fund managers were able to select REITs that outperformed. We surmise that the outperformance mainly derives from the endemic abilities of managers to uniquely process REIT-specific information and generate private valuation beliefs that lead to profitable investment decisions.

Can delegated portfolio managers successfully select Real Estate Investment Trusts (REITs) that outperform passive indexes? This question is at the heart of an ongoing debate in the literature. Extant studies, all of which examine real estate mutual fund returns, provide conflicting results. O'Neal and Page (2000) report that 28 REIT fund managers were unable to generate excess returns from 1996 to 1998. Gallo, Lockwood and Rutherford (2000), studying 24 REIT funds operating from 1991 to 1997 , document a fund return pattern suggesting that managers were able to successfully shift portfolio weights across REIT property types, but were unable to identify outperforming individual REITs within a given property type. Kallberg, Liu and Trzcinka (2000) show that 44 REIT

*Mason School of Business, College of William and Mary, Williamsburg, VA 23185 or Gjergji.Cici@mason.wm.edu.

**School of Hotel Administration, Cornell University, Ithaca, NY 14853 or jc81@ cornell.edu.

${ }^{* * *}$ Mason School of Business, College of William and Mary, Williamsburg, VA 23185 or scott.gibson@mason.wm.edu. 
funds from 1986 to 1998 generated positive alphas, particularly during down real estate markets. Three recent studies find no evidence of outperformance: Lin and Yung (2004) for REIT funds over 1993 to 2001, Rodriguez (2007) for 35 REIT funds over 1999 to 2004 and Chiang et al. (2008) for 55 REIT funds over 1982 to 2003.

The mixed evidence to date is entirely generated from analyses of returns at the REIT-fund level. Our study differs in that we are the first to examine fund holdings and trading activities involving individual REIT shares. The advantage of this approach is that we can better disentangle fund managers' ability to select individual REITs that outperform from performance due to passive strategies based on REIT characteristics (e.g., property type) or non-REIT holdings (e.g., Treasury securities held for liquidity purposes). The detailed information provided in fund holdings and trades data allows us to address two important concerns raised by Hartzell, Mühlhofer and Titman (2010) about the benchmarks used in studies that examine REIT fund performance using fund-level returns. First, holdings and trades data allow us to directly address the concern that fund portfolios may be over or underweighted on certain REIT characteristics and that these weights change through time. Our benchmarking methodology explicitly controls for portfolio rebalancing that alters characteristic weights by matching REITs held by funds at each report date to benchmark portfolios of REITs that share similar characteristics. Second, we directly address the concern about fund portfolios containing non-REIT securities that typically do not represent pure plays on underlying real estate ownership. Holdings data allow for benchmark return calculations that exclude non-REIT securities owned by funds at each report date.

This study examines a comprehensive, survivorship-bias-free sample of 96 REIT mutual funds operating from 1995 through 2006. The first set of tests analyzes returns to hypothetical portfolios formed by market-value weighting REIT holdings reported each quarter. We adjust the returns of the holdings portfolios for risk in two ways. The first is a characteristic-based procedure along the lines of Daniel et al. (1997), where the buy-and-hold return for each REIT is benchmarked against the buy-and-hold return of a portfolio consisting of REITs that share similar characteristics. The second is a regression-based procedure following Hartzell, Mühlhofer and Titman (2010), where alpha is calculated by regressing portfolio excess returns on the returns of benchmark portfolios comprising REITs with certain characteristics.

Results show evidence consistent with REIT-selection ability. First, we benchmark the returns of holdings portfolios against only the Center for Research in Security Prices/Ziman REIT index. Using the characteristic-based procedure, 
we find that holdings portfolios outperformed the overall REIT index by a significant $1.82 \%$ average over the subsequent year. Using the regression-based procedure, we find outperformance averaged a significant $1.57 \%$ per annum.

Next, we benchmark the returns of holdings portfolios against the CRSP/Ziman Property-Type REIT Indices. We find that controlling for property type decreases the magnitude of outperformance, but to a still significant $0.91 \%$ over the subsequent year for the characteristic-based method and $0.84 \%$ per annum for the regression-based method. The decrease in magnitude is consistent with part of fund managers' outperformance of the overall REIT index being attributable to successfully shifting portfolio weights across property types. The ability to successfully shift from underperforming to outperforming property types is consistent with the findings of Gallo, Lockwood and Rutherford (2000). However, unlike that paper, we find that significant outperformance remains after controlling for property type, implying that not all of the outperformance is explained by shifting portfolio weights across property types.

Finally, we add controls for size and momentum. Jointly controlling for property type, size and momentum, outperformance of the holdings portfolio averaged a significant $0.68 \%$ over the subsequent year for the characteristic-based method and $1.45 \%$ per annum for the regression-based method. Thus, results are consistent with fund managers' REIT-selection abilities extending beyond an ability to shift across property types and beyond naïve strategies that load on REITs with certain size or momentum characteristics.

Results to this point are based on portfolios formed using funds' REIT holdings. Chen, Jegadeesh and Wermers (2000) argue that increased power of securities selection ability can be attained by studying trades as opposed to holdings because trades reflect current valuation beliefs whereas holdings represent past decisions. Both for robustness and to increase the testing power, we repeat tests by forming portfolios based on funds' REIT trades over the previous quarter. The evidence of REIT-selection ability is stronger when portfolios are based on recent buys versus holdings. The magnitude of outperformance for the buy portfolios is larger than for the holdings portfolios for both the characteristic-based and regression-based results regardless of model specification. Jointly controlling for property type, size and momentum, outperformance of the buy portfolio is a significant $1.27 \%$ over the subsequent 12 months for the characteristic-based method and $2.55 \%$ per annum for the regression-based method.

The documented outperformance after controlling for property type, size and momentum is potentially attributable to a number of trading strategies based on REIT property holdings' characteristics, relative public/private real estate 
valuations and REIT financial characteristics possibly considered by fund managers for holding and trading REIT shares. We investigate four strategies, some suggested by industry practitioners and others by findings of extant academic research.

The first strategy we examine is based on the geographic concentration of REIT property holdings. The question as to whether REITs become more valuable with geographically concentrated property holdings has been addressed in several studies. Gyourko and Nelling (1996), Capozza and Seguin (1998) and Ambrose et al. (2000) find no economic benefit to geographic concentration. However, in a follow-up study, Capozza and Seguin (1999) discover a link between REIT value and geographic focus. Their interpretation of results is that value derives not from enhanced cash flow, but rather from improved REIT liquidity because investors can more efficiently research REIT real estate holdings that are geographically concentrated. To investigate whether the documented outperformance we report derives from a trading strategy based on the geographic concentration of the real estate held by REITs, we split funds into those holding REITs with more versus less geographically concentrated real estate holdings. Suggesting that such a strategy is not the source of the documented outperformance, we find that both fund subgroups exhibited significant outperformance regardless of how portfolio returns are adjusted for risk. Noteworthy, characteristic-based results, particularly in the later years of our sample period, show some evidence that funds invested in more geographically concentrated REITs outperformed funds invested in less geographically concentrated REITs. The finding, however, does not carry over to the regression-based results.

The second strategy, advocated by Green Street Advisors (2007), among others, is a trading guideline based on REIT share prices relative to NAV estimates. Specifically, buying REITs that trade at the greatest discounts and selling those that trade at the greatest premiums generates excess returns. Gentry, Jones and Mayer (2004) present evidence that following the NAV trading strategy produces significant positive benchmarked returns. The strategy's premise is straightforward. Prices of REITs ought to reflect fundamental real estate values. ${ }^{1}$ To investigate, we split the sample into funds holding REITs trading at relatively high discounts (i.e., low NAV-to-price ratios) and those holding REITs trading at relatively low discounts (or at premiums). Suggesting that the NAV trading strategy was not the source of the documented outperformance, we find that the REIT holdings of both fund subgroups exhibited significant outperformance.

\footnotetext{
${ }^{1}$ Observed time-series differences between REIT share prices and private market real estate values that mean revert indirectly suggests profitable trading opportunities depending on reversion speed (Liow 2003).
} 
The third strategy we investigate is based on the dividend yield offered by REITs. Dividend yield can serve as a proxy for fund investment styles seeking yield income versus capital appreciation. Presumably, funds targeting yield income will focus on REITs offering high yields, with payouts often in excess of regulatory requirements. Funds targeting capital appreciation also will consider REITs offering lower yields, with payouts near mandated levels and pursuing activities such as development and acquisition joint ventures designed to promote share price growth. We find that funds buying REITs offering high yields exhibited significant outperformance that did not differ from the outperformance of funds buying REITs offering lower yields. The successful REIT-selection ability we document, therefore, does not appear to be the direct result of following a naïve strategy based on the dividend yield offered by REITs.

The final strategy considered is based on the financial leverage employed by the REIT. The outperformance we document may be related to some funds focusing on highly leveraged REITs characterized by higher risk and expected return not fully accounted for in our benchmarking methods. Results show that funds focusing on REITs with higher leverage exhibited significant outperformance that was no different than funds focusing on REITs with lower leverage. Thus, naïve strategies based on the financial leverage employed by REITs do not appear to explain the successful REIT-selection ability we document.

Each of the four trading strategies we evaluate relies on publicly available information-historic geographic concentrations, dividend yields and leverage to a greater degree, Green Street NAV estimates to a lesser degree. The comparative analysis and regressions show that none of the strategies fully explains why fund managers were able to select REITs that outperformed. We surmise that the outperformance mainly derives from the endemic abilities of managers to uniquely process REIT-specific information and generate private valuation beliefs that lead to profitable investment decisions.

The remainder of the article is organized as follows. The next section describes the data and sample composition. The third section explains the methodologies used to benchmark REIT returns. The fourth section describes the design of tests aimed at uncovering the source of managers' apparent ability to generate positive alpha, and it then presents and interprets the results. Concluding remarks are made in the fifth section.

\section{REIT Holdings Data and Sample Construction}

REIT mutual fund holdings data from January 1995 to December 2006 were obtained from Thomson/CDA. For a given date and fund, the database provides 
the name and identifier of each REIT held and the number of REIT shares held. Although funds were mandated to publicly report holdings semiannually prior to June 2005, most funds voluntarily reported holdings to Thomson/CDA quarterly. ${ }^{2}$ Funds were required to publicly report holdings quarterly after June 2005. Monthly returns for individual REITs and REIT indices returns were obtained from the CRSP/Ziman Real Estate Data Series.

To construct the sample, we merged the Thomson/CDA holdings database with the CRSP mutual fund database using WRDS' MFLINK, a data set that links Thomson/CDA fund identifiers with those from the CRSP mutual fund database. Both databases are free of survivorship bias. We identified REIT funds using investment objective classifications provided in the CRSP mutual fund database and screened for funds with names containing variations of the phrases REAL ESTATE, REIT and REALTY. We further excluded index funds from our list of potential matches and excluded incorrectly matched funds. All share classes belonging to a common fund are aggregated and treated as a single fund. The resulting sample includes 96 actively managed REIT funds.

Table 1 provides descriptive information for the 96 REIT funds. Panel A reports the number of funds that operated during each year and the total assets under management by all funds each year. Growth was dramatic over the 12-year sample period, with the number of REIT funds increasing from 21 in 1995 to 70 in 2006 and the total assets under management increasing from $\$ 1,629$ million in 1995 to $\$ 39,197$ million in 2006 . Panel B reports fund-level total assets, number of securities held, expense ratios and turnover rates for the 96 funds.

\section{Can Fund Managers Select REITs that Outperform?}

Fund holdings data allow us to examine REIT-selection ability using methods that explicitly account for portfolio rebalancing that alters characteristic weights. The first characteristic we control for is property type. Gallo, Lockwood and Rutherford (2000) present evidence suggesting that fund managers outperform the overall REIT indexes by shifting portfolio weights to property types that subsequently outperformed. We further consider controls for size, book-to-market and momentum. To determine whether size, book-to-market or momentum effects exist over our sample period, we compute the returns on characteristic-benchmark portfolios constructed using only REITs along the lines of Fama and French (1993) and Carhart (1997).

\footnotetext{
${ }^{2}$ One possible incentive to provide pre-2005 quarterly reports is a clientele effect whereby some investors who value more frequent disclosure are willing to pay higher fees (see Frank et al. 2003).
} 
Table 1 a Fund of REIT sample size and characteristics.

\begin{tabular}{llc}
\hline \hline Panel A: Sample Size by Year & & \\
\hline Year & $\begin{array}{l}\text { Number } \\
\text { of Funds }\end{array}$ & $\begin{array}{c}\text { Total Assets } \\
\text { (\$ Millions) }\end{array}$ \\
\hline 1995 & 21 & 1,629 \\
1996 & 25 & 3,004 \\
1997 & 33 & 8,764 \\
1998 & 54 & 9,771 \\
1999 & 62 & 8,111 \\
2000 & 64 & 9,192 \\
2001 & 57 & 10,349 \\
2002 & 58 & 12,884 \\
2003 & 64 & 16,982 \\
2004 & 66 & 26,630 \\
2005 & 72 & 44,338 \\
2006 & 70 & Median \\
\hline Panel B: Fund Characteristics & & $\$ 104$ Million \\
\hline & Mean & 39 \\
\hline Total assets & $\$ 228$ Million & $1.51 \%$ \\
Number of securities held & 43 & $45 \%$ \\
Expense ratio & $1.49 \%$ &
\end{tabular}

Note: This table reports summary characteristics of the 96 funds of REITs in our sample. Panel A reports the number of funds and the total assets under management by all funds each year. Panel B reports the mean and median total assets, number of REITs held, management expenses and portfolio turnover rate. The number of securities held is from the Thomson mutual fund holdings database, and all other data are from the CRSP mutual fund database.

The size portfolio return is the return on small capitalization REITs less the return on large capitalization REITs, where small is defined as below the median capitalization REIT and large is defined as above. The book-to-market portfolio return is the return on high book-to-market REITs less the return on low book-to-market REITs, where high is defined as above 30th percentile and low is defined as below the 70th percentile of REITs sorted on book-to-market. The momentum portfolio return is the return on high-momentum REITs less the return on low-momentum REITs, where high is defined as above 30th percentile and low is defined as below the 70th percentile of REITs sorted on cumulative returns over months $t-2$ to $t-12$.

The average return for the size, book-to-market and momentum portfolios are found in Table 2. The size portfolio return of 49 basis points per month and the 
Table 2 a Average return of the REIT Fama-French factors during 1995-2006.

\begin{tabular}{lccc}
\hline \hline & Size & Book-to-Market & Momentum \\
\hline Mean (\%/Month) & $0.49^{* *}$ & 0.15 & $0.61^{* * *}$ \\
$t$-stat. & $(2.47)$ & $(0.56)$ & $(2.58)$ \\
\hline
\end{tabular}

Note: This table reports average returns for the three Fama-French factors constructed using the universe of all REITs over the 1995-2006 period. The factors, Size, Book-toMarket and Momentum are the return differentials between the small cap and large cap REITs, high and low book-to-market REITs and positive and negative return-momentum REITs, respectively. The approach for constructing the factors is based exactly on Fama and French (1993). Associated $t$-statistics are reported in parentheses. ${ }^{* * *},{ }^{* *}$ and ${ }^{*}$ denote significance at the $1 \%, 5 \%$ and $10 \%$ levels, respectively.

momentum portfolio return of 61 basis points per month are both statistically significant. The return on the book-to-market portfolio differs insignificantly from zero. Our finding of a size and momentum effect over our 1995-2006 sample period mirrors the finding by Hartzell, Mühlhofer and Titman (2010) of a size and momentum effect over their 1995-2005 sample period. Based on the results above, we control for property type, size and momentum when we adjust returns for risk.

\section{Benchmarking Procedures}

We take two approaches to adjust returns for risk. The first is a characteristicbased benchmarking procedure close in spirit to Daniel et al. (1997). We create benchmark portfolios consisting of REITs that share similar characteristics. We then compute a value-weighted buy-and-hold return for each benchmark portfolio over 3-, 6- and 12-month holding periods. The benchmark-adjusted return for each REIT is its buy-and-hold return minus the buy-and-hold return of the appropriate benchmark portfolio over the same holding period.

For a baseline, we report results when the return of each REIT is compared to the return of the CRSP/Ziman REIT Index. ${ }^{3}$ We drill down into fund performance by controlling for managers' ability to successfully shift portfolio property types. Using the CRSP/Ziman REIT property type designation, we

${ }^{3}$ The CRSP/Ziman REIT Index is a capitalization-weighted index comprising all REITs traded on the NYSE, AMEX and NASDAQ exchanges. Results are qualitatively similar if the NAREIT REIT Index is used. The NAREIT REIT Index is a capitalizationweighted index sponsored by the National Association of Real Estate Investment Trusts and includes all tax-qualified REITs with common shares traded on the NYSE, AMEX and NASDAQ National Market List under certain size- and liquidity-related eligibility criteria (see http://www.nareit.com/library/domestic/ftseQandA.pdf for more detail on the eligibility criteria). 
match every REIT on each fund holdings report date with one of the following eight value-weighted CRSP/Ziman REIT Property-Type Indices: Health Care, Industrial/Office, Lodging/Resorts, Residential, Retail, Self-storage, Diversified or Unclassified. Drilling down further, we create benchmark portfolios that control for the documented size and momentum effects. We independently rank REITs each month based on market capitalization at the beginning of the month; REITs below the median are categorized as small and those above as large. We independently rank REITs each month based on cumulative past-sixmonth returns; REITs above the median are categorized as high momentum and those below as low momentum. Jointly controlling for property type, size and momentum results in $8 \times 2 \times 2=32$ benchmark portfolios.

The second risk-adjustment approach is a regression-based benchmarking procedure following Hartzell, Mühlhofer and Titman (2010). First, we compute monthly returns to value-weighted portfolios comprising aggregate fund holdings or trades. The portfolios are updated quarterly to reflect the most recent holdings disclosures of each fund. We then calculate alphas by regressing the excess return of these portfolios on the excess returns of benchmark portfolios comprising REITs with certain characteristics. Again as a baseline, we report results from a regression that includes only the excess return on the value-weighted CRSP/Ziman REIT Index as an independent variable. We then control for property type by adding the excess returns on the CRSP/Ziman REIT Property-Type Indices as independent variables. Finally, we control for size, book-to-market and momentum by adding the excess returns on characteristicbased portfolios constructed using only REITs (as described earlier) in the spirit of Fama and French (1993) and Carhart (1997).

\section{Evidence Based on Funds' REIT Holdings}

We examine the returns of a hypothetical portfolio that mimics the aggregate holdings of all funds' REIT holdings reported each quarter. We start by calculating, for each fund $i$, the number of shares held in REIT $j$ at the end of quarter $t$ for all quarters during the sample period. Next, the REITs held by all funds in portfolio-formation quarter $t$ are grouped into aggregate value-weighted holdings portfolios. ${ }^{4}$ Forming an aggregate holdings portfolio for each quarter results in a single return time series, thus avoiding potential cross-sectional return correlations across funds that could affect standard errors. This approach also allows us to correct for potential time-series dependence in the standard errors using the Newey-West correction.

\footnotetext{
${ }^{4}$ This approach is identical to that used by Chen, Jegadeesh and Wermers (2000) who study the performance of aggregate holdings for domestic equity mutual fund holdings.
} 
Panel A of Table 3 presents results when the return of each REIT return is benchmarked against the return of its matching characteristic portfolio for 12-, 6- and 3-month holding periods following the holdings portfolio formation date. The first row shows strong evidence that fund managers possess the ability to identify individual REITs that subsequently outperformed the overall REIT index. The REIT portfolios held by funds outperformed the CRSP/Ziman REIT index by a statistically significant $1.82 \%$ average over the subsequent year. The six- and three-month holding periods also show significant outperformance, but of a lesser magnitude. Interestingly, funds are currently required to report portfolio holdings to the SEC quarterly in conjunction with their fiscal year. These reports must be filed within 60 days after the end of the fiscal quarter. To the extent that reports are filed in a timely manner, the continuation of positive benchmark-adjusted returns beyond one quarter suggests a profitable trading rule.

Comparing the second-row returns benchmarked against property-specific REIT indices with the first-row returns benchmarked against the overall REIT index, we find evidence of fund managers' ability to outperform the overall REIT index by successfully shifting portfolio weights across property types. Benchmarking returns against the corresponding CRSP/Ziman Property-Type REIT Indices, we find funds' REIT holdings outperformed by a significant $0.91 \%$ average over the subsequent year. Thus, property-type shifting incrementally accounted for 91 basis points of the 182 basis points of outperformance of the overall REIT index. The six- and three-month holding periods also show outperformance of a lesser magnitude when we control for property type. The ability to successfully shift from underperforming to outperforming property types is consistent with the findings of Gallo, Lockwood and Rutherford (2000). However, unlike that paper, we find that not all of the outperformance is explained by shifting portfolio weights across property types. ${ }^{5}$

The third row reports returns benchmarked jointly for property type, size and momentum. Results show that funds' REIT holdings outperformed other REITs of the same property type with similar size and momentum characteristics by a significant $0.68 \%$ average over the subsequent 12 -month holding period.

\footnotetext{
${ }^{5}$ The result contrasts with the finding of Gallo, Lockwood and Rutherford (2000) that managers were able to successfully shift portfolio weights across REIT property types but were unable to identify outperforming individual REITs within a given property type. Of course, the contrasting results may be attributable to the fact that Gallo, Lockwood and Rutherford (2000) study a smaller sample (24 funds) over a shorter period (1991 to 1997). Another possibility is that Gallo, Lockwood and Rutherford (2000) infer shifts in portfolio property-type weights from fund-level returns. In contrast, our results based on trades in individual REITs allow us to compute actual shifts in portfolio property weights.
} 
Table 3 a Performance of REIT holdings.

\begin{tabular}{|c|c|c|c|c|c|c|c|}
\hline \multicolumn{8}{|c|}{ Panel A: Characteristic Benchmarks } \\
\hline \multirow{2}{*}{\multicolumn{3}{|c|}{$\begin{array}{l}\text { Benchmarking } \\
\text { Method }\end{array}$}} & \multicolumn{5}{|c|}{ Holding Period } \\
\hline & & & \multicolumn{2}{|c|}{ Annual } & \multicolumn{2}{|l|}{ Semiannual } & Quarter \\
\hline \multicolumn{3}{|c|}{ CRSP/Ziman } & \multicolumn{2}{|c|}{$1.82^{* * *}$} & $1.05^{* * *}$ & & $0.47^{* * *}$ \\
\hline \multicolumn{3}{|c|}{ REIT Index } & \multicolumn{2}{|c|}{$(3.07)$} & $(3.32)$ & & $(2.84)$ \\
\hline \multicolumn{3}{|c|}{ CRSP/Ziman property-type } & \multicolumn{2}{|c|}{$0.91^{* * *}$} & $0.56^{* * *}$ & & $0.26^{* * *}$ \\
\hline \multicolumn{3}{|c|}{ REIT index } & \multicolumn{2}{|c|}{$(3.51)$} & $(3.70)$ & & $(3.28)$ \\
\hline \multicolumn{3}{|c|}{ CRSP/Ziman property-type } & & $0.68^{* * *}$ & $0.45^{* * *}$ & & \multirow{2}{*}{$\begin{array}{l}0.20^{* * *} \\
(3.03)\end{array}$} \\
\hline size and 1 & omentum-adj & usted & $(3.30$ & & $(3.94)$ & & \\
\hline \multicolumn{8}{|c|}{ Panel B: Regression Benchmarks } \\
\hline & \multicolumn{6}{|c|}{ Independent Variables } & \multirow{5}{*}{ Adj. $R^{2}$} \\
\hline & & $C R S P /$ & & & & & \\
\hline & & Ziman & & & & & \\
\hline & Alpha & REIT & & Book-to- & & Property & \\
\hline & (\%/Month) & Index & Size & Market & Momentum & Factors & \\
\hline \multirow[t]{2}{*}{ Model 1} & $0.13^{* *}$ & $1.04^{* * *}$ & & & & Not & $97.70 \%$ \\
\hline & $(2.41)$ & $(77.07)$ & & & & included & \\
\hline \multirow[t]{2}{*}{ Model 2} & $0.07^{*}$ & $0.89^{* * *}$ & & & & Included & $98.53 \%$ \\
\hline & $(1.70)$ & $(14.30)$ & & & & & \\
\hline \multirow[t]{2}{*}{ Model 3} & $0.12^{* * *}$ & $0.90^{* * *}$ & $-0.06^{* * *}$ & $-0.04^{* * *}$ & 0.003 & Included & $98.63 \%$ \\
\hline & $(2.69)$ & $(14.86)$ & $(-2.71)$ & $(-2.77)$ & $(0.14)$ & & \\
\hline
\end{tabular}

Note: This table reports performance results of REIT holdings. Panel A reports results from characteristic-based benchmarking of REIT holdings. At the end of every calendar quarter, all share holdings of each REIT are aggregated across all funds and placed in a hypothetical portfolio whose weights are determined by the market value of aggregated shares as of the end of the quarter. The aggregated portfolio is held from 3 to 12 months after portfolio formation and is balanced every calendar quarter. In the first row, the buyand-hold return on the CRSP/Ziman Value-Weighted REIT Index is subtracted from the buy-and-hold return for each REIT for the same period. In the second row, the buy-andhold return on the CRSP/Ziman Value-Weighted Property-Type Index is subtracted from the buy-and-hold return for each REIT with the same property type (diversified, health care, industrial/office, lodging/resorts, residential, retail, self-storage or unclassified). In the third row, the buy-and-hold return on a benchmark portfolio that jointly controls for property type, size and momentum is subtracted from the buy-and-hold return for each REIT for the same period. We independently rank REITs each month based on market capitalization at the beginning of the month; REITs below the median are categorized as small and those above as large. We independently rank REITs each month based on cumulative past-six-month returns; REITs above the median are categorized as high momentum and those below as low momentum. Thus, there are $8 \times 2 \times 2=32$ benchmark portfolios that jointly control for property type, size and momentum. Panel B reports monthly alpha estimates and factor loadings from regression-based benchmarking models. The common factors CRSP/Ziman REIT Index, Size, Book-to-Market and Momentum are the return differentials between the CRSP/Ziman Value-Weighted REIT Index and risk-free rate, small cap and large cap REITs, high and low book-to-market REITs and positive and negative return-momentum REITs, respectively. Property factors are the return differentials for each of the CRSP/Ziman Value-Weighted PropertyType Indexes and the risk-free rate. Associated Newey-West-corrected $t$-statistics are reported in parentheses. ${ }^{* *},{ }^{* *}$ and ${ }^{*}$ denote significance at the $1 \%, 5 \%$ and $10 \%$ levels, respectively. 
Again, the six- and three-month holding periods also show significant outperformance. Thus, results are consistent with fund managers' REIT-selection abilities extending beyond an ability to shift across property types and beyond naïve strategies that load on REITs with certain size or momentum characteristics.

Panel B of Table 3 presents the regression-based results. When the return of the portfolio formed quarterly from funds' REIT holdings is regressed on only the CRSP/Ziman REIT index, alpha is a significant $0.13 \%$ per month or $1.57 \%$ on an annualized basis, economically inline with the characteristicbased estimate. When the return on the property indices are added to the regression model, alpha decreases to a significant $0.07 \%$ per month or $0.84 \%$ per annum, again economically in line with the characteristic-based estimate. Finally, when the return on size, book-to-market and momentum portfolios are added to the regression model, alpha is a significant $0.12 \%$ per month or $1.45 \%$ per annum. The increase in the magnitude of alpha when we add the returns of the characteristic portfolios is consistent with the negative loading on the size portfolio. Funds tended to buy more liquid, larger REITs that underperformed smaller REITs over the sample period. Thus funds' REIT-selection abilities were more impressive once we account for the fact that they tended to hold larger REITs.

\section{Evidence from REIT Ownership Changes}

In this section, we base portfolio formation on changes in REIT ownership that occurred during the prior quarter rather than on REIT holdings. Chen, Jegadeesh and Wermers (2000) argue that ownership changes are more indicative of securities-selection ability because they reflect more current valuation beliefs, whereas holdings represent an amalgamation of past decisions. To form the aggregate buy portfolio, we sum all REITs purchased by all funds in a given quarter, weighting each purchase by the dollar value of the trade. A similar procedure is followed to form the aggregate sell portfolio in a given quarter. Specifically, to calculate quarterly REIT ownership changes for fund $i$, we compute the change in the number of shares held in REIT $j$ from the end of quarter $t-1$ to the end of quarter $t$ for all quarters during the sample period. ${ }^{6}$ REITs bought or sold by all funds in portfolio-formation quarter $t$ are grouped into value-weighted buy-and-sell portfolios.

Table 4, organized in the same way as Table 3, shows that the evidence of REITselection ability is stronger when portfolios are based on recent buys versus

\footnotetext{
${ }^{6}$ We fully account for REIT splits when computing quarterly fund trades by using the cumulative adjustment factors from the CRSP return file.
} 


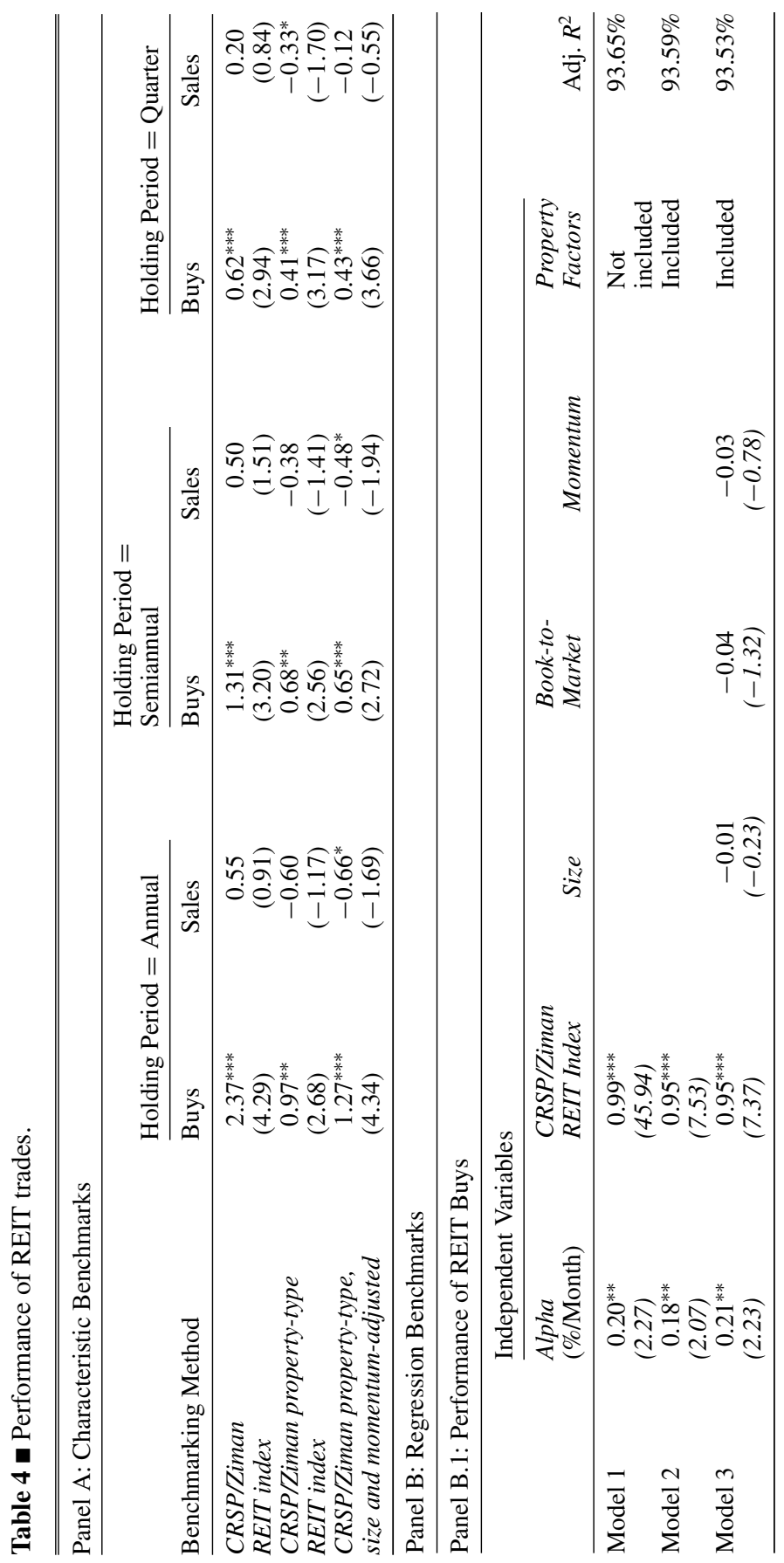




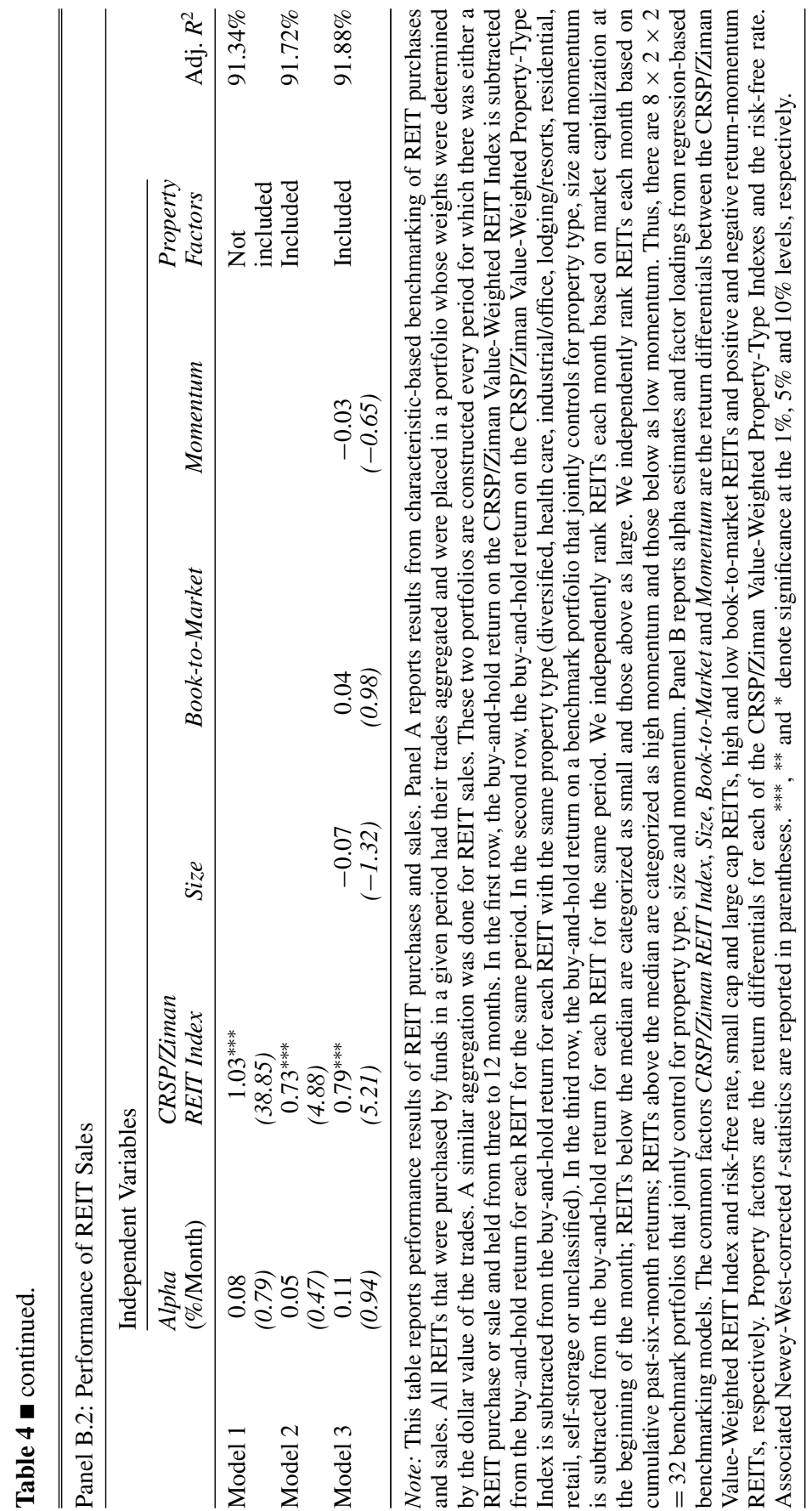


holdings. The magnitude of outperformance for the buy portfolios in Table 4 is larger than for the holdings portfolios in Table 3 for both the characteristicbased and regression-based results regardless of model specification. As for the holdings portfolios, buy portfolios show a smaller, but significant, level of outperformance when we control for property type. Jointly controlling for property type, size and momentum, outperformance of the buy portfolio is a significant $1.27 \%$ over the subsequent 12 months for the characteristic-based method and $2.55 \%$ per annum for the regression-based method.

Turning to sales portfolios, it is important to recognize that REIT mutual fund managers face short-selling restrictions. Managers cannot take action when a particular REIT is believed overpriced relative to its assessed fundamental value, unless it is currently owned. Thus, short-selling restrictions create an asymmetry in that fund managers can only take unfettered action when any REIT (within their allowable realm) is believed underpriced. Under the presumption that fund managers possess REIT-selection ability, trading profits are generated by buying underpriced REITs and then by selling when REITs approach target assessments of fundamental values. The empirical implication is that REITs sold ought to exhibit subsequent returns that differ insignificantly from zero. Generally, this is what we find. We do observe, however, a few entries for the sales portfolios in Panel A that are negative and significant at the $10 \%$ level.

\section{Investment Styles and Fund Performance}

Results to this point show that fund managers, after controlling for property type, size and momentum, demonstrated an ability to select REITs that outperformed. Now, we investigate funds' REIT holdings and buys to see whether this ability was concentrated in funds run by managers who followed certain investment strategies. Four strategies analyzed in the next sections come under investigation-some suggested by industry practitioners and others by findings of extant academic research.

\section{Geographic Concentration of REIT Property Holdings}

The first strategy we examine is based on the geographic concentration of REIT property holdings. The question as to whether REITs become more valuable with geographically concentrated property holdings has been addressed in several studies cited earlier. The majority of these studies fail to uncover any economic benefit from assembling geographically concentrated portfolios. Only Capozza and Seguin (1999) link REIT valuation to what they describe as "geographic focus." They postulate value derives from improved REIT liquidity because investors can more efficiently research geographically concentrated 
property cash flows. We investigate whether funds holding REITs with more geographically concentrated real estate holdings outperformed funds holding REITs with more geographically dispersed holdings during two distinctly different investment windows.

The methodology is as follows. For each REIT, using data on the precise geographic location of each property in its portfolio, we calculate the Herfindahl index as a measure of its geographic property concentration. The property portfolio weights for calculating the Herfindahl index are based on the reported "amount" managed in each geographic location. The units in which the "amount" managed in each geographic location are expressed differently from REIT to REIT based on property type. For example, some REITs reported total square footage managed in each geographic area whereas others reported the total number of hotel rooms managed in each geographic area. ${ }^{7}$

After we compute the Herfindahl index for each REIT, all REITs are ranked within the same CRSP property type designation and assigned quintile scores based on the Herfindahl index values. By ranking REITs within each property type, we address the unit measurement issue across REITs managing different types of properties. For each fund portfolio and holdings report, we calculate an average Herfindahl quintile score weighted by the dollar value of each REIT holding. At the beginning of the quarter, all funds are then ranked by their average Herfindahl quintile score and sorted into two groups: high (i.e., above the median geographic concentration) and low (i.e., below the median geographic concentration).

The geographic location data for the properties managed by REITs were collected for two snapshots that came from two different data sources. The 2006 snapshot contains property location data for 2006 from SNL. SNL provides information about properties currently held in REIT portfolios, but unfortunately it does not allow subscribers access to the same information during historical periods. SNL devotes substantial resources to ensure that their data are of the highest quality by doing control and verification data checks that often involve directly contacting REITs. The SNL data cover detailed geographic locations

\footnotetext{
${ }^{7}$ Ideally the market value of the properties managed in a particular geographic area would be desirable for computing the Herfindahl index. Nonetheless, because these data are not reported in the 10-Ks REIT companies file with the SEC (or by SNL), we use the total property size or units managed in each geographic location as reported by the REITs in their $10-\mathrm{K}$ reports. Although we do not believe that this would create any directional biases for our results because of well-known size and value correlations, resulting noise and measurement error would work against us finding more stock-picking ability among any particular group of funds that favoring REITs with certain geographic concentration in their portfolios.
} 
for 60 REITs. The 2000 snapshot of property locations were hand collected from individual $10-\mathrm{Ks}$ filed with the SEC by all REITs during that year and covers 81 REITs. Although we spent considerable effort cleaning the handcollected data, verification checks based on other sources as done by SNL could not be undertaken.

As discussed in Mühlhofer (2008), REITs abide by property-selling restrictions to retain tax-exempt status. Specifically, REITs must hold acquired properties for four years and may not sell in excess of $10 \%$ of their net asset base at one time. Given the exogenously induced stability of REIT property portfolios, we extend Herfindahl index values for the two years surrounding each snapshot. Herfindahl index values calculated using 2000 data for REITs therefore are extended to years 1998, 1999, 2001 and 2002. Herfindahl index values calculated using 2006 data are extended to 2004 and 2005.

Table 5 presents buy-and-hold benchmarked returns mimicking aggregate REIT fund holdings and trades for portfolios categorized by their Herfindahl measure and held for a period of 12 months after portfolio formation. Panel A presents results based on combined data for the 1998-2002 and 2004-2006 windows from both a characteristic-based and a regression-based approach. Regardless of the benchmarking method used, holdings returns for both the high and low geographic concentration portfolios show outperformance that is economically and statistically significant. Buy returns are also consistently positive for both the high and low geographic concentration portfolios, but they show weaker statistical significance.

The last two columns present the differences between the high and low geographic concentration portfolios. The differences based on the holdings portfolios using the characteristic-based approach are positive and statistically significant for all benchmarking methodologies. The differences based on the buy portfolios are positive for all benchmarking methodologies, but only statistically significant at conventional levels when the CRSP/Ziman Property-Type REIT Index is used to benchmark REIT returns. The regression-based approach results in smaller differences that are not statistically significant.

To check the robustness of the geographic-concentration results for the two property snapshots, we run the analysis separately for the 1998-2002 and 2004-2006 windows. This is a worthwhile exercise because the data corresponding to these two subperiods come from two different sources. Panel B.1 reports results for the 2004-2006 window. Again, the high-minus-low differences based on the holdings portfolios from the characteristic-based analysis prove positive and statistically significant for all benchmarking methodologies. Although the differences based on buy portfolios are also all positive, none 


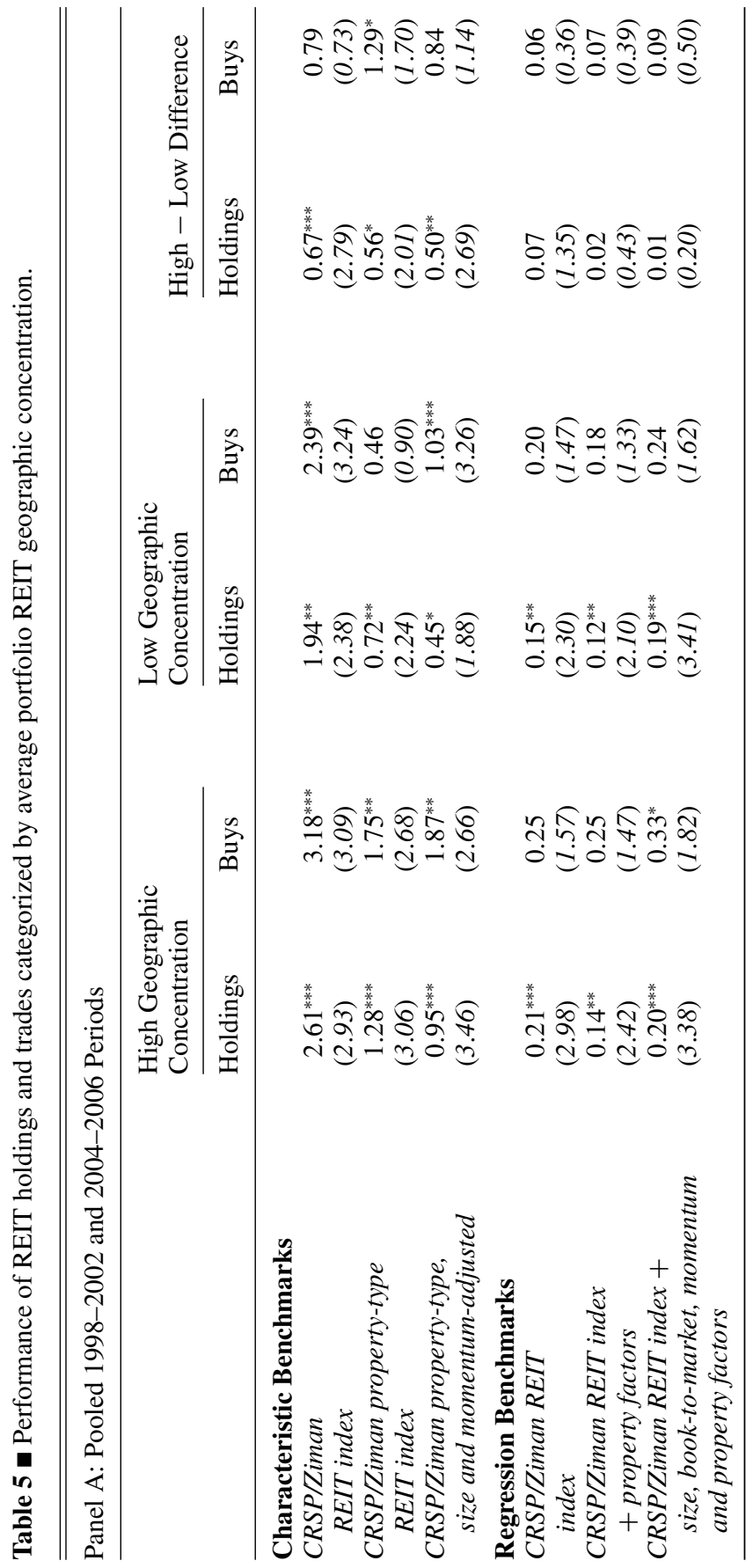




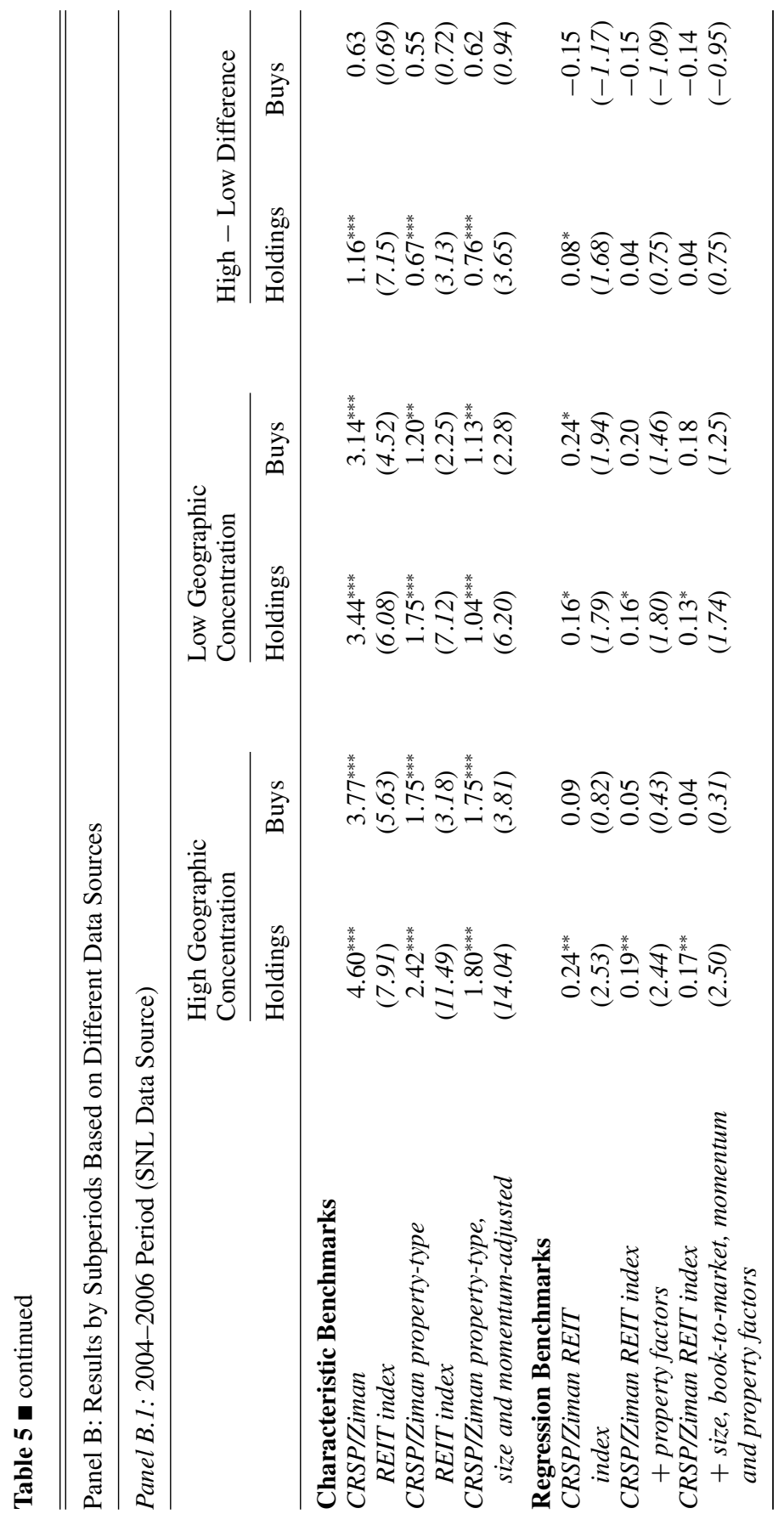




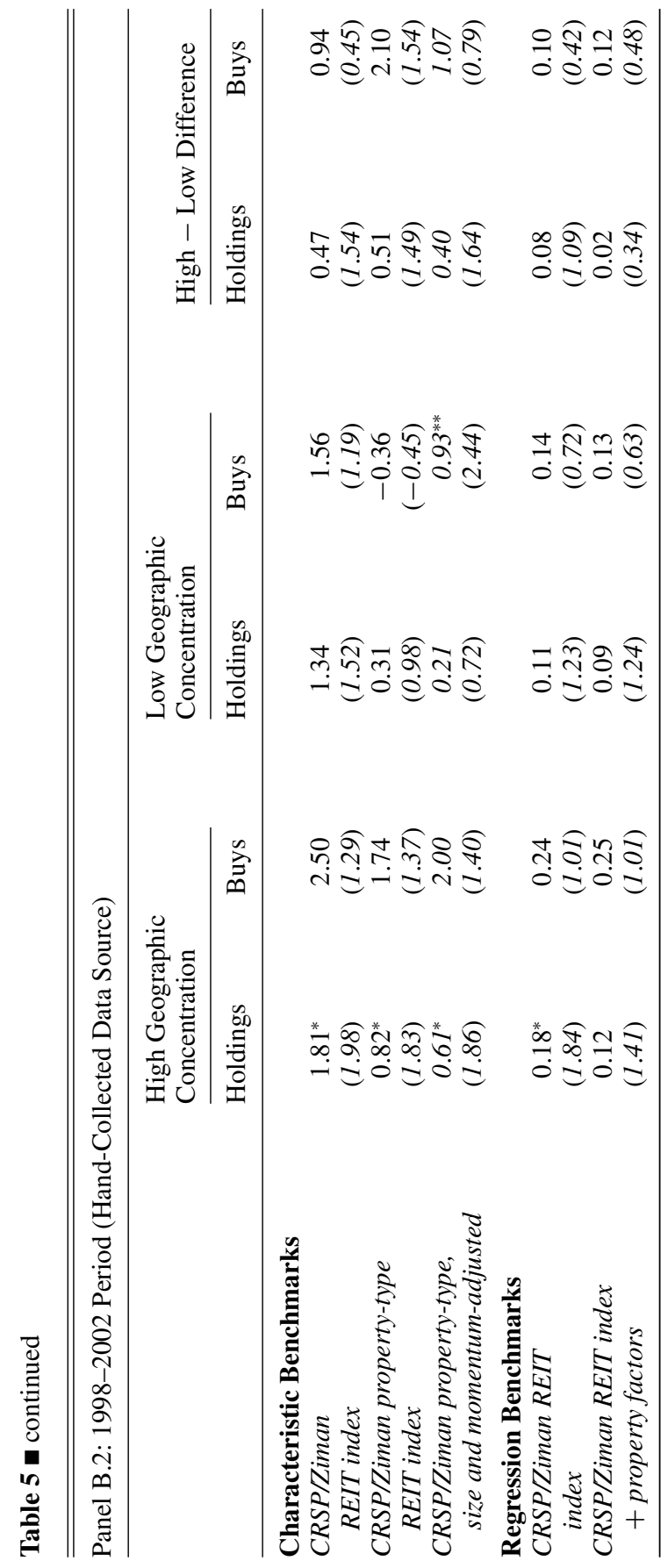




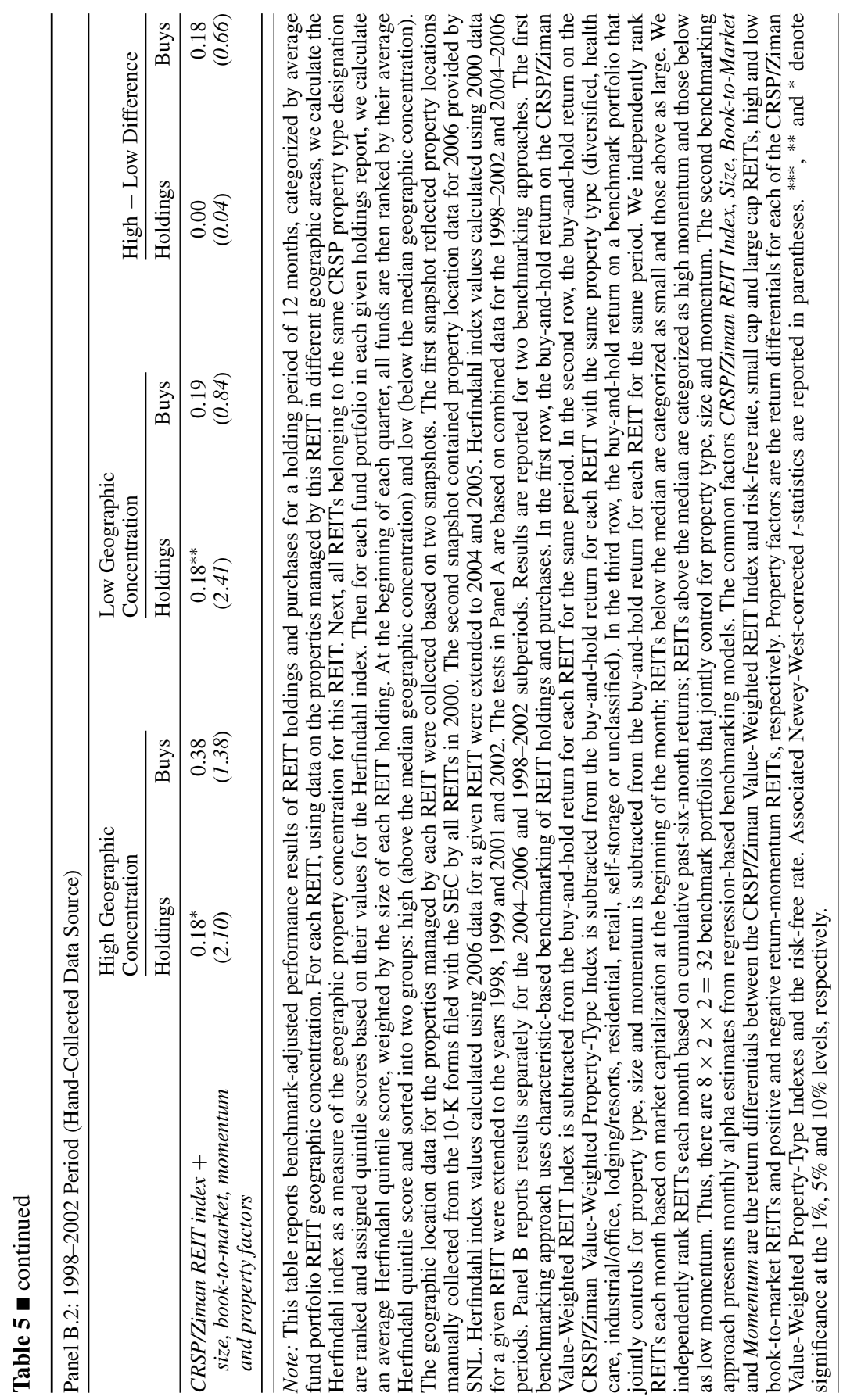


are statistically significant at conventional levels. As we found for the pooled sample, the differences between portfolio return profiles for high and low geographic concentrations diminish in size and statistical significance with the regression-based approach.

Panel B. 2 reports results for the 1998-2002 window. We observe that all differences based on both holdings and buy portfolios are positive; however, the differences are statistically insignificant. The absence of statistical significance during this window may be associated with noise from the $10-\mathrm{K}$ property data.

Overall, we find that both high and low geographic concentration subgroups exhibited significant outperformance regardless of how portfolio returns are adjusted for risk, suggesting that strategy based on geographic concentration is not the source of the documented outperformance. We cannot entirely rule out, however, that funds invested in more geographically concentrated REITs outperformed funds that invested in less geographically concentrated REITs, but the evidence presented here is weak. These mixed results encourage further empirical research into the geographic concentration of REIT real estate holdings and trading when better, more comprehensive geographic data become available.

\section{REIT Share Prices Relative to NAV Estimates}

The second strategy advocated, for example, by Green Street Advisors (2007), embraces a trading guideline based on REIT share prices relative to NAV estimates. Some evidence exists (Gentry, Jones and Mayer 2004) in support of an excess return generating strategy of buying REITs that trade at the greatest discounts and selling those that trade at the greatest premiums. The strategy's premise is straightforward-prices of REITs drift away from fundamental real estate values, but ought to eventually reflect these values subject to mean reversion speed.

Description of the methodology for analyzing this strategy follows. Using NAV estimates provided by Green Street Advisors for a subset of REITs and REIT prices from CRSP, we calculate for each REIT during each period the ratio of Green Street's NAV per share estimate to the price per share. ${ }^{8}$ Next, for each fund portfolio in each given holdings report, we calculate an average NAV/P number, weighted by the size of each REIT holding. At the beginning of the

\footnotetext{
${ }^{8}$ Out of the 331 distinct REITs held by at least one REIT mutual fund and for which there was valid share price data from CRSP, there are 102 distinct REITs for which there were monthly NAV estimates from Green Street Advisors.
} 
period, funds are ranked by their average NAV/P ratios and sorted into two groups: high (i.e., above the median) and low (i.e., below the median).

Table 6 presents buy-and-hold benchmarked returns mimicking aggregate REIT fund holdings and buys for portfolios categorized by their average NAV/P ratios and held for a period of 12 months after portfolio formation. Regardless of the benchmarking method used, holdings returns for both the high and low NAV/P portfolios show outperformance that is economically and statistically significant. Buy returns are also consistently positive and significant for the low NAV/P portfolio. Buy returns for the high NAV/P portfolio are positive, but they are statistically significant only when returns are benchmarked against the CRSP/Ziman REIT index using the characteristic method. Curiously, buy returns for the high NAV/P portfolio are significantly larger than for the low NAV/P portfolio when we control jointly for property type, size and momentum. The result, however, is not robust for the other specifications. Overall, results suggest that the NAV trading strategy was not the source of the documented outperformance.

\section{Dividend Yield Offered by REITs}

The third strategy we investigate is based on the dividend yield offered by REITs. Dividend yield serves as a proxy for fund investment styles seeking periodic income versus capital appreciation. Presumably, funds targeting yield will focus on REITs offering relatively high payouts, often in excess of regulatory requirements. On the other hand, funds targeting capital appreciation gravitate toward REITs offering lower yields, with payouts near mandated levels and engaged in activities such as development and acquisition joint ventures designed to promote share price growth.

For each REIT and year using market capitalization data from CRSP and total annual dividend data from Compustat, we calculate dividend yields. For each fund portfolio in a given holdings report, we calculate the average dividend yield, weighted by the size of the REIT's holdings. At the beginning of each period, funds are ranked by their average dividend yield and sorted into two groups: high (i.e., above the median) and low (i.e., below the median).

Table 7 presents buy-and-hold benchmarked returns mimicking aggregate REIT fund holdings and trades for portfolios categorized by their average dividend yield ratios and held for a period of 12 months after portfolio formation. Regardless of the benchmarking method used, holdings returns for both the high and low dividend yield portfolios show outperformance that is economically and statistically significant. Buy returns are also consistently positive and significant for the low dividend yield portfolio. Buy returns for the high dividend 


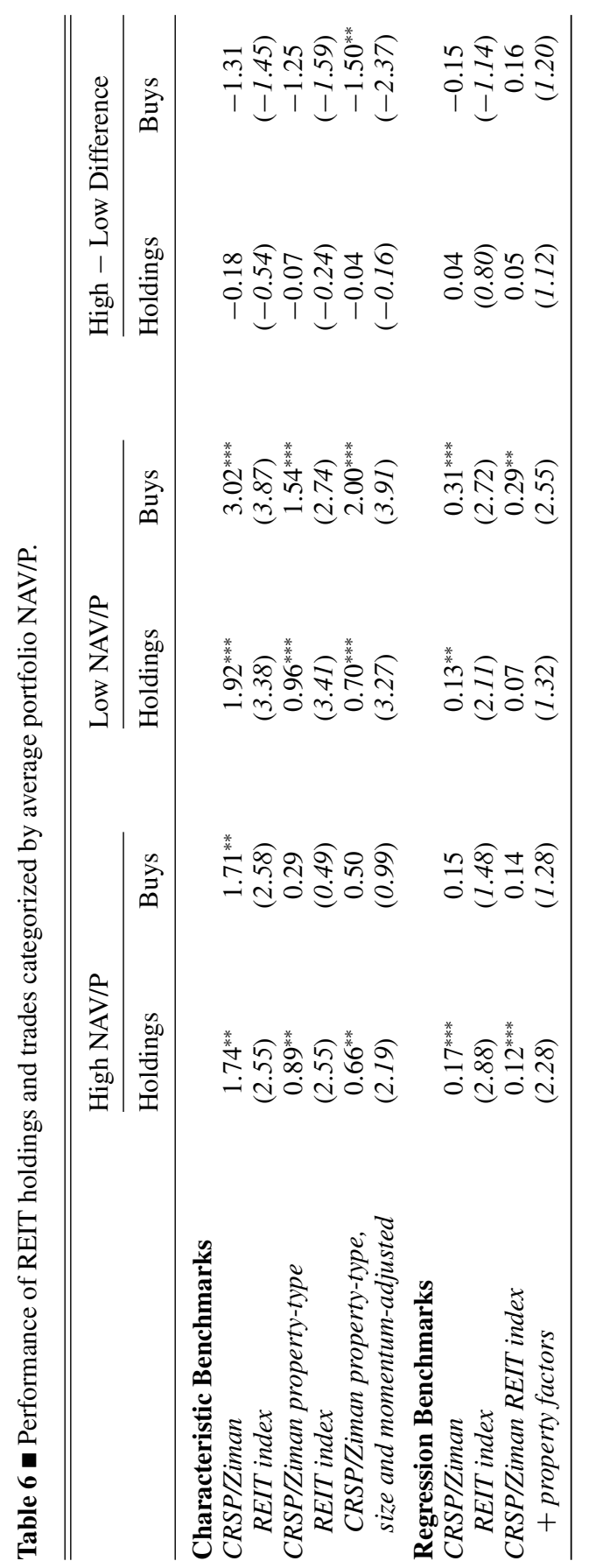




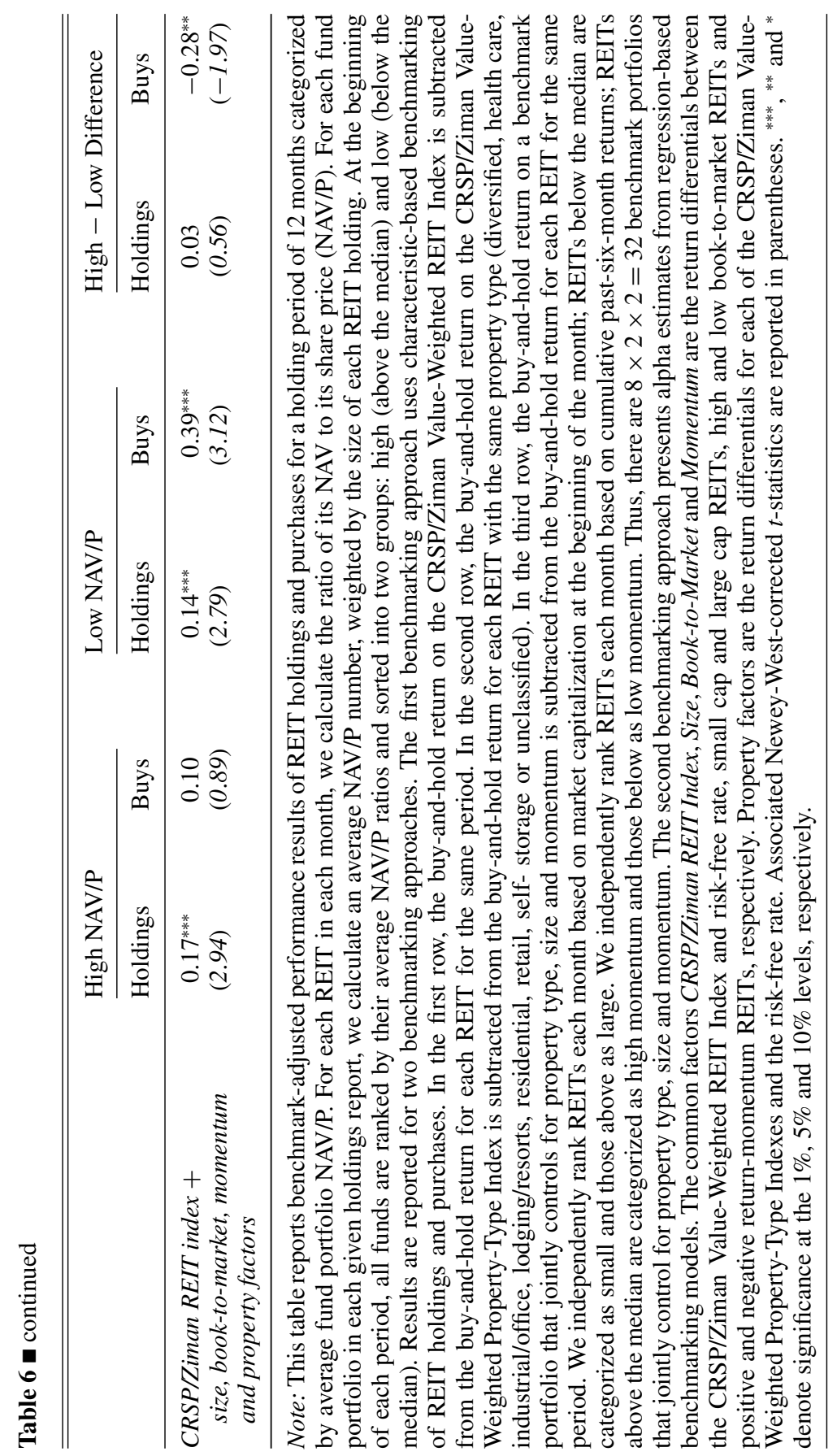




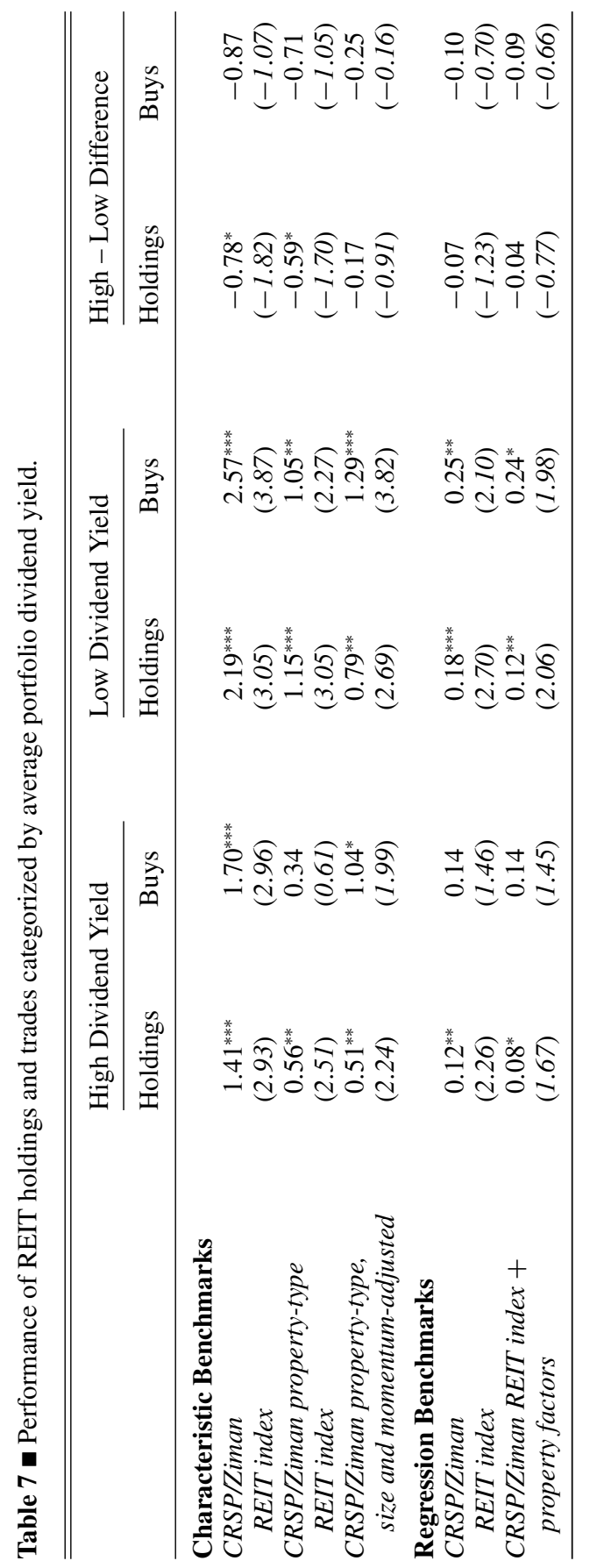




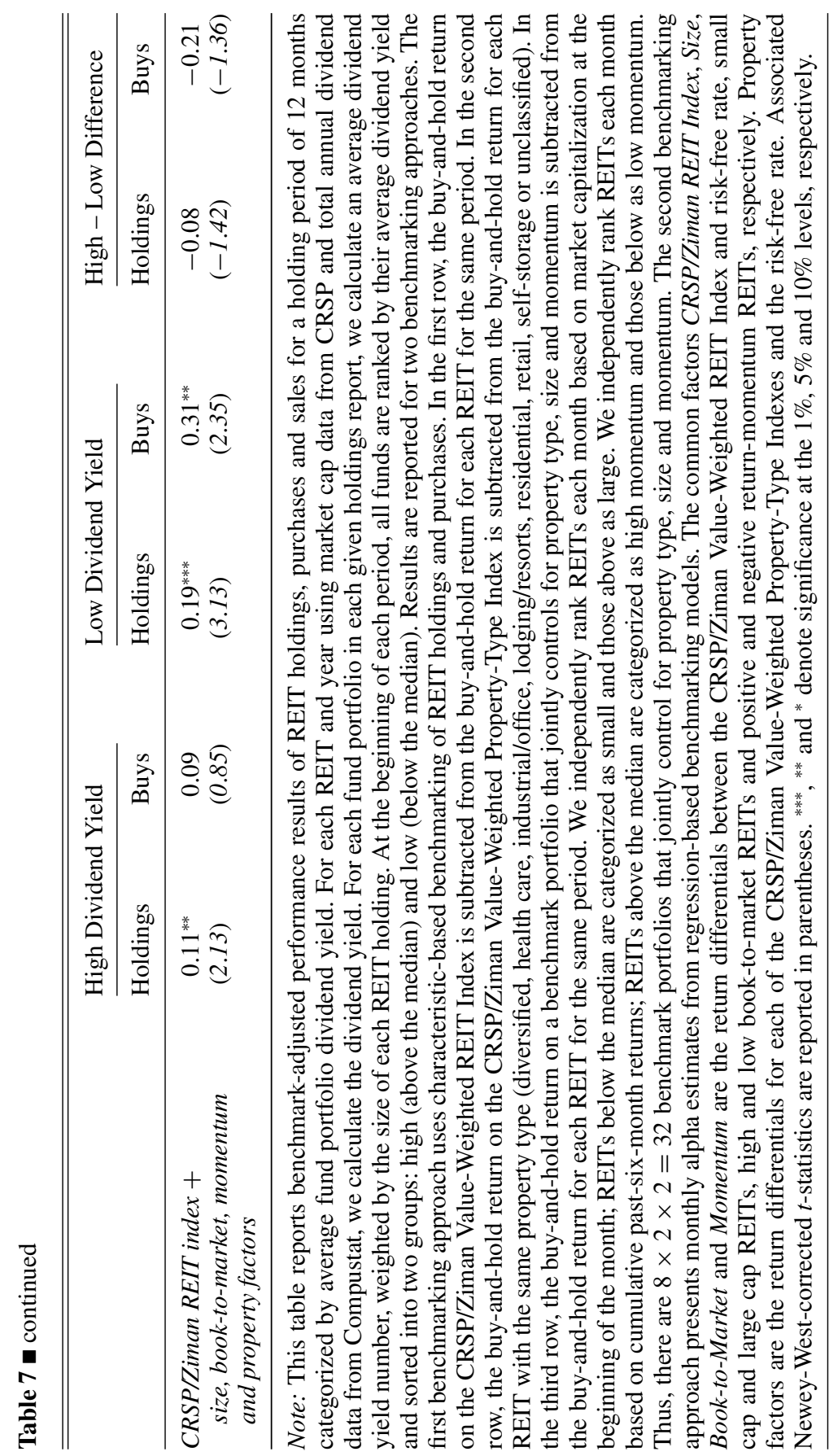


yield portfolio are positive, but they are not statistically significant for all specifications. Although outperformance is smaller in magnitude for the high dividend yield portfolios compared to low dividend yield portfolios, we do not observe a consistent pattern of statistically significant differences across benchmarking models. In sum, adherence to a dividend-trading rule does not appear to be the source of the documented outperformance.

\section{Financial Leverage Employed by the REIT}

The final strategy considered is based on the financial leverage employed by REITs. Potentially, the outperformance we document relates to funds focusing on highly leveraged REITs characterized by higher risk and expected return not fully accounted for in our benchmarking methods.

For each REIT and year using market capitalization data from CRSP and debtlevel data from Compustat, we calculate REIT leverage ratios. For each fund portfolio in a given holdings report, we calculate an average leverage ratio, weighted by the size of REITs' holdings. At the beginning of the period, funds are ranked by their average leverage ratio and sorted into two groups: high (i.e., above the median) and low (i.e., below the median).

Buy-and-hold benchmarked returns mimicking aggregate REIT fund holdings and trades for portfolios categorized by their average leverage ratios and held for a period of 12 months after portfolio formation appear in Table 8 . Regardless of the benchmarking method used, holdings and buy returns for the low-leverage portfolios show significant outperformance. Holdings and buy returns for the high-leverage portfolios are also consistently positive, but they are not statistically significant for all benchmarking specifications. Although outperformance is consistently smaller in magnitude for the highleverage portfolios compared to low-leverage portfolios, we do not observe any statistically significant differences across any of the benchmarking specifications. In sum, a strategy based on the financial leverage employed by REITs does not appear to explain the successful REIT-selection ability by fund managers.

\section{Conclusion}

The experimental setting for empirical testing in this article embodies a unique set of market conditions, institutional details and information costs. To compete, real estate mutual fund managers absorb sizeable expenses to acquire information associated with the unique characteristics of the underlying real estate assets that, by law, must dominate the portfolios of assets held by funds. This investment environment may yield premiums for efficiency and economies 


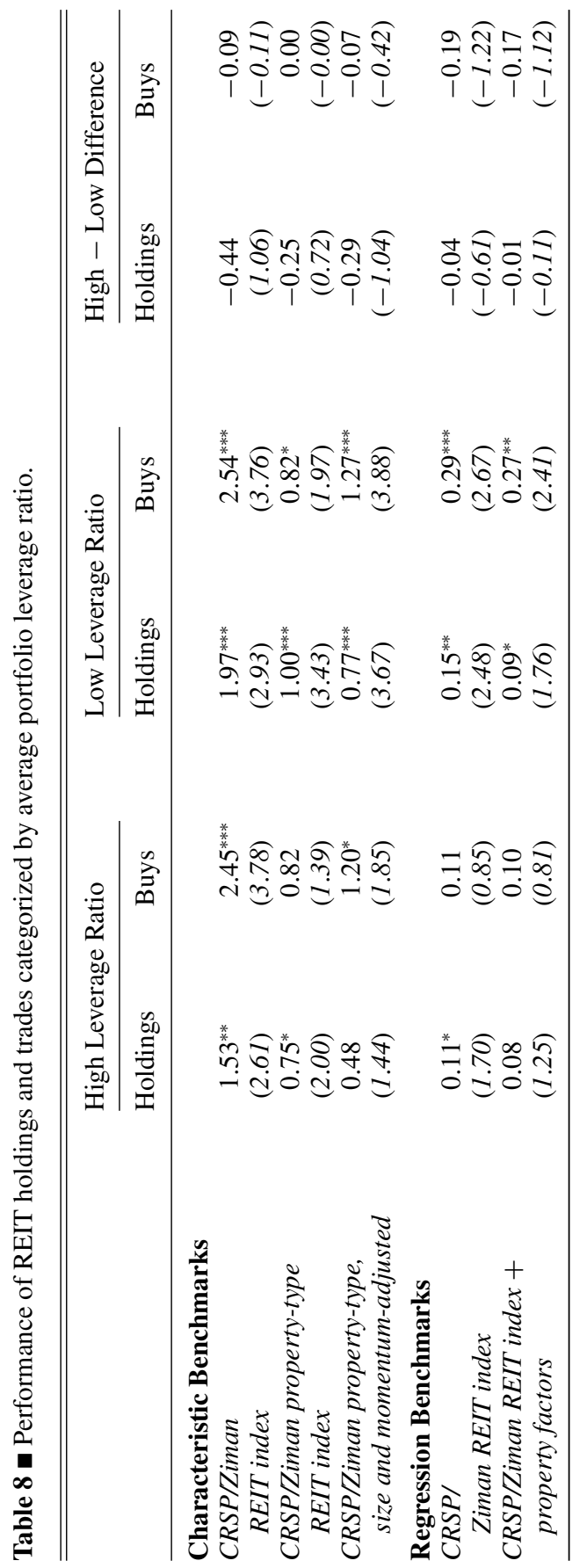




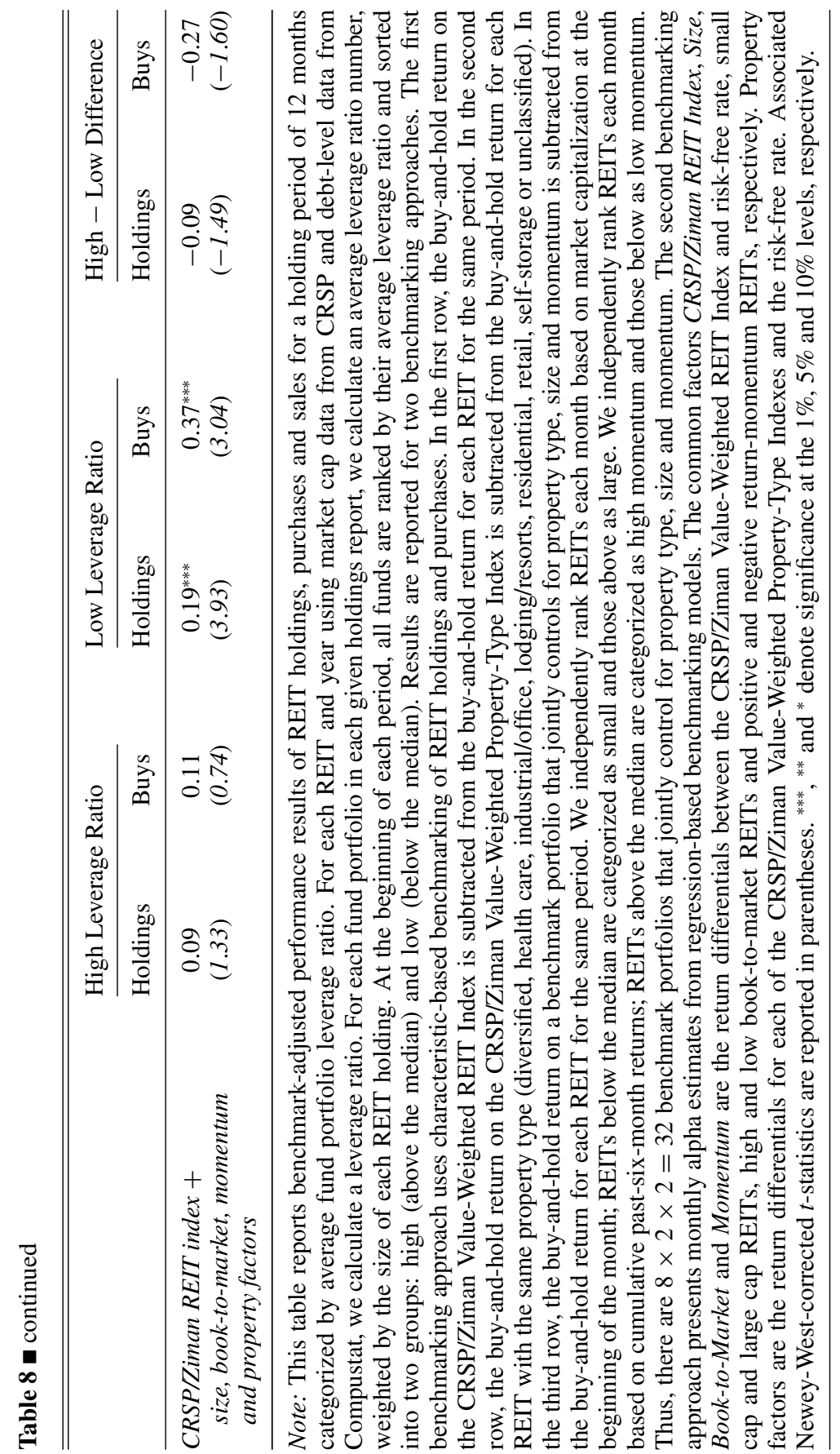


of scale in information gathering and thus represents a special case for testing mutual fund managers' abilities to generate excess returns.

Does the costly research of fund managers lead to the selection of REITs that outperform? Our results show that REIT mutual fund managers, on average, generated significant positive alpha with their REIT-selection ability, as predicted by Grossman and Stiglitz (1980). Managers' ability to select outperforming REITs is robust after controlling for REIT property type, return momentum and size. Additional tests also show that managers' ability to select outperforming REITs went beyond naïve trading rules based on public information related to geographic concentration, NAV-to-price ratios, income and appreciation styles or leverage of the underlying REITs. Rather, evidence is consistent with outperformance deriving from the endemic abilities of managers to uniquely process REIT-specific information and generate private valuation beliefs that lead to profitable investment decisions.

We are indebted to Green Street Advisors for contributing their NAV data for this study.

\section{References}

Ambrose, B., S. Ehrlich, W. Hughes and S. Wachter. 2000. REIT Economies of Scale: Fact or Fiction? The Journal of Real Estate Finance and Economics 20: 211224.

Capozza, D.R. and P.J. Seguin. 1998. Managerial Style and Firm Value. Real Estate Economics 26: 131-150.

1999. Focus, Transparency, and Value: The REIT Evidence. Real Estate Economics 27: 587-619.

Carhart, M.M. 1997. On Persistence in Mutual Fund Performance. The Journal of Finance 52(1): 57-82.

Chen, H., N. Jegadeesh and R. Wermers. 2000. The Value of Active Mutual Fund Management: An Examination of the Stockholdings and Trades of Fund Managers. Journal of Financial and Quantitative Analysis 35: 343-368.

Chiang, K., K. Kozhevnikov, M. Lee and C. Wisen. 2008. Further Evidence on the Performance of Fund of Funds: The Case of Real Estate Mutual Funds. Real Estate Economics 36: 47-61.

Daniel, K., M. Grinblatt, S. Titman and R. Wermers. 1997. Measuring Mutual Fund Performance with Characteristic-Based Benchmarks. The Journal of Finance 52: 1035-1058.

Fama, E.F. and K.R. French. 1993. Common Risk Factors in the Returns on Stocks and Bonds. Journal of Financial Economics 33(1): 3-56.

Frank, M., J. Poterba, D. Shackelford and J. Shoven. 2003. Copycat Funds: Information Disclosure Regulation and the Returns to Active Management in the Mutual Fund Industry. Working Paper. Massachusetts Institute of Technology.

Gallo, J., L. Lockwood and R. Rutherford. 2000. Asset Allocation and the Performance of Real Estate Mutual Funds. Real Estate Economics 28: 165-184. 
Gentry, W., C. Jones and C. Mayer. 2004. REIT Reversion: REIT Price Adjustments to Fundamental Value. Working Paper No. 10850. National Bureau of Economic Research. Green Street Advisors. 2007. Green Street's NAV-Based Pricing Model. Available at http://www.greenstreetadvisors.com/methodology.

Grossman, S. and J. Stiglitz. 1980. On the Impossibility of Informationally Efficient Markets. American Economic Review 70: 393-408.

Gyourko, J. and E. Nelling. 1996. Systematic Risk and Diversification in the Equity Market. Real Estate Economics 24: 493-515.

Hartzell, J., T. Mühlhofer and S. Titman. 2010. Alternative Benchmarks for Evaluating Mutual Fund Performance. Real Estate Economics 38: 121-154.

Kallberg, J., C. Liu and C. Trzcinka. 2000. The Value Added from Investment Managers: An Examination of Funds of REITs. Journal of Financial and Quantitative Analysis 35: 387-408.

Lin, C. and K. Yung. 2004. Real Estate Mutual Funds: Performance and Persistence. Journal of Real Estate Research 26: 69-93.

Liow, K. 2003. Property Company REIT Price and Net Asset Value: A Mean Reversion Perspective. The Journal of Real Estate Finance and Economics 27: 235-255.

Mühlhofer, T. 2008. Why do REIT Returns Poorly Reflect Property Returns? Unrealizable Appreciation Gains due to Trading Constraints as the Solution to the Short-Term Disparity. Working Paper. Indiana University.

O'Neal, E. and D. Page. 2000. Real Estate Mutual Funds: Abnormal Performance and Fund Characteristics. Journal of Real Estate Portfolio Management 6: 239-247.

Rodriguez, J. 2007. A Critical Look at the Forecasting Ability of Real Estate Mutual Fund Managers. Journal of Real Estate Portfolio Management 13: 99-106. 